\title{
Language Education and Education Challenges in The Mondial Era
}

\author{
Sri Budiyono \\ Lecture of Widya Dharma University, \\ Klaten, Central Java, Indoensia \\ sribudyono15@gmail.com
}

\author{
Gunawan Budi Santosa \\ Lecture of Widya Dharma University, \\ Klaten, Central Java, Indonesia \\ gunawanbudisantosa1963@gmail.com
}

\begin{abstract}
The term mondial has the same meaning as the global term, comprehensive, universal, global, spatial. In its development this term can be interpreted as "world-wide". The statement can be interpreted or drawn a conclusion that the term mondial is something that is related to the things that are new and general, all lines wear, all lines follow, and all lines undergo. The "line" limit is not only limited to local concepts, but also national, and even international. For it is clear that the era of mondial is a new era that all activities are done quickly and at the same time also digital or comprehensive / worldwide. Mondial era marked by the existence of a great competition, which occurs in all lines and dimensions, which accompanied the business competition, technology, information, industry, and even education itself. Current changes and developments are the impact of scientific and technological progress, as well as the intermingling of multidimensional influences from all sides. It is necessary to study multicultural approaches and models with a global perspective to meet the needs of learners, teachers, policy makers (school principals, heads of departments, and district heads), including the community itself. In relation to the above statement, it is necessary to anticipate early to follow and improve themselves to pay attention to technological progress in various aspects, such as: programmatic curriculum, qualified and professional teachers, learning process which is accompanied by the progress of time, proactive development of learners, evaluation of learning by using multidimensional approach, ready and ready to face rapid and enormous changes in free market opposition. The hope, by following the speed of technology, can give birth to human beings who are highly competitive and tough, and have qualified human resources to win the free market competition that is always progressive in accordance with the alignment and demands of life.
\end{abstract}

Keywords-obstacles and challenges; language education; mondial era; multidimensional; technological developments

\section{INTRODUCTION}

The occurrence of the era of globalization or also called the mondial era, can have a double impact or a beneficial impact (posiotif) and adverse impacts (negative). A beneficial impact is a risk that can provide the widest possible opportunity of cooperation that can be personal, group or organization, nawsional, and even international. On the other hand, if the insurers are unable to compete because of the low human resources (HR), the consequences will be their own loss and lagging far behind the development of the technology. Therefore, the challenge of the nation (in large scale) in the future is to increase competitiveness and competitive advantage in all sectors, both real and monetary sectors, relying on human resources, technology and management capabilities without compromising the comparative advantage that has been owned our nation, and in the form of following the pace of its development. (compare: Kaku, 1997: Friedman, 2005; Arief 2009; Saflin, 2016; Mukmin, 2017; Budiyono, 2017; Rifai, 2018; Budiyono, 2018).

The occurrence of free trade should be utilized by all parties in various aspects of life, including aspects of education, where education is required to face rapid and enormous changes in the opposition of the free market too, thus certainly can give birth to human beings who are struggling and competitiveness high, tough, and capable. This high competitiveness and fight will determine the level of progress, efficiency, and quality of the nation to be able to win the tight free market competition era.

Similarly, what happens in the line of education and economics that in this free market era (read: the mondial era) is also characterized by the freight of travel freight, services, capital, and labor that goes freely, then the demand of production technology is getting longer the higher the level, the higher the level of education demanded of the workers and even the learners. Then in the next development, the progress of communication technology causes the absence of distance and boundary between one person with another, group one with other group, and between country one with other country. Communications between countries and nations can take place very quickly, precisely. and easy. So also the development of information across the world can be easily accessed through information technology such as through the internet. Transfer of money and capital investment by foreign entrepreneurs can also be done in seconds, which is short and fast.

Responding to the problem, in this mondial era, of course, every citizen is required to be prepared, fix themselves in facing and responding, and undergo this competition. Countries with citizens who are aware of the early age to fix themselves by responding positively increase capabilities, surely able to compete in the flow of globalization and digitization.

Herein lies the latest issues in education - that every time, day, week, month and even year - is always changing. Indonesia's first president statement, Ir. Sukarno, who declared that "Whoever does not follow the flow of revolution will be crushed by the wheel of the revolution" 
This statement is really true. The statement can be directly interpreted that he wishes to even be "demanding" all citizens (citizens of Indonesia or other citizens even) to always be alert and responsive to face any changes and developments of the times, whether it concerns ideology, politics, social, culture, defense and security.

\section{LITERATURE REVIEW}

Live in the digital age, all of which are practical, fast, economical, and even dynamic surely there will be attitudes to be faced, responded to, respected, lived, and even enjoyed. For this reason, in the discussion of this article need a sequence of discussions related to obstacles, challenges, decisions, and expectations. The four things are parsed as follows below.

\section{A. Obstacles}

The word "obstacle" in English is often defined as obstacle, hurdle, barrier, hindrance, retartment, block, retardation, retarder, cramp, blockade, rub, handicap, impediment, hitch, cumber, encumbrance, trammel, setback, crab, traverse, ring fance, stonewalling, stumbling blocks, debarment, hold-up, crimp, strike, marplot, and even can also be interpreted or called complication. These terms are special words that describe something that is how difficult or severe obstacles to be faced.

In connection with a specific term that describes the difficulties or barriers of society (including learners) in the face of the complexity of life in the mondial era is the stuttering of technological advances. Technological advances are fast-paced and innovative, creative, demanding the community to be willing and able to follow the rate of development. Without willingness, ability, and tenacity (adversity), they (the community and the learner) will surely be left behind who are ultimately a total failure in their life (unable to work, difficult to communicate, difficult to transact, etc.).

For that, all levels, both student/learner level, teacher (including lecturer), principal (including rector), policy maker (institutional control) must synergize well and be kind, full of awareness to strive to be willing and able to know and follow technological progress in this era of mondial.

\section{B. Challenge}

Khaerudin (1999) said that the presence of globalization is a big challenge for education. Some of the challenges he thinks are concerns 1) are: 1) related to economic added value; 2) the challenge of conducting research; 3) the challenge to improve the nation's competitiveness; and 4) tantrangan to face the emergence of new invasion and colonialism in the field of science and technology.

For more details these four problems can be described as follows.

First, the first challenge is related to the economic problem of how the community (including the learners) seeks to increase the added value of how to increase the productivity of national work as well as economic growth and equity, in order to maintain and promote sustainable development. Indeed, the main tasks that bewrkitan with economic equity is the task of the government. However, if not followed and diringi by the consciousness of the citizens this is tantamount to a lie. Because whatever the government's efforts are based on and based on its citizens this will have an impact on the difficulty of promoting sustainable development.

Second, the second challenge is the problem of research. With the advanced level of civilization of a nation, of course, also associated with the speed of technology. Similarly, what happened to the research problem. To conduct a quality research, it is necessary to understand and balance the progress of the reform era and the transformation of the society's structure, from traditional agrarian society to modern-industrial-informationcommunication society, and how its implications for the improvement and development of the quality of life of human resources.

Third, the third challenge that challenges that are global/mondial. The era of global society is an era that opens up new vast expectations, but also new threats are facing (Pranggono, 2001). The dark side of the mondial era, the potential for social inequality, personal rights violations, copyright, unemployment, impact on families, and so on relating to moral values will surely emerge. In the increasingly fierce global competition there will be competition on all fronts (political, social, economic, and educational, and defense and security).The tight competition is not only about personal or group, even also automatically arise competition between nations and countries in producing quality creative works as a result of thought, discovery and mastery of science, technology and art.

Fourth, this last challenge is a challenge to the emergence of new invasion and colonialism in the field of Science and Technology, which replaces the invasion and colonialism in the field of politics and economy.

The four basic issues are the main problems that must be addressed faced, lived, and even enjoyed by seeking harmony and balance to be able to walk in synergy in the face of technological progress that all this digital.

\section{Decision}

The decision to be wise and prudent, positive thinkink in the face of the pace of technological development in the digital all-digital era, is the right choice and accurate. The decision to accept, honor, follow, and practice according to the demands of the needs is the most appropriate and appropriate form of responsibility.

In connection with the above statement, of course we can be principled and take attitude, and by realizing that we all (especially the younger generation) have the potential to 
always be better, and vice versa exactly if we (read: the younger generation) is not careful in addressing the pace of development that all our digital can potentially to be not good. For that we need an effort to create a human worth and dignity, namely by providing a character education, noble character, nourish the spirit of the students to have semangangat learning high.

Education is a conscious effort aimed at achieving a form of improvement on all fronts, in all aspects of life. In the educational effort, the participation of parents, community, government, community leaders, teachers (including lecturers), and also students, is necessary. To that end, all these lines must be mutually rounded up to respond positively, think positive, act positive. These things will get a positive decision as well.

\section{Hope}

\section{1) From a personal point of view}

Attitude, conscious, patience, passion, acting and positive thinking, working hard, must be owned by all the younger generation. This is not easy. Because naming a positive attitude and shaping a young generation of character is very difficult. However, if all lines, all aspects of life are not supportive will experience significant obstacles in the face of obstacles and challenges in this era of mondial.

\section{2) From the point of view of facilities and infrusructure}

It should be realized that the cost of education is high enough so that the community must have to prepare ahead of time to be able to follow the speed of education. Related to $\mathrm{h}$ al above Sahlan (2013) said that there are four things that must be prepared to welcome the future related to the preparation of education fund. These four things include the following.

\section{a) Prepare the current educational costs.}

The current educational cost is relatively high so if the people do not realize and do not prepare far-away days for the cost of education of their sons and daughters will certainly object in the financing.

\section{b) Rising cost of education from year to year}

The public is aware enough for this problem. Be fully aware that the cost of education from year to year increase. For that, the preparation for saving is a basic requirement that will inevitably have to prepare it early on.

\section{c) The economy is not always good}

For the private sector (non-permanent employees) must be well aware that their income is uncertain or fluctuating. Sometimes high income, and vice versa that earnings can go down at any time. A management that regulates the rate of finance must be well understood.

\section{d) Physical man is not always healthy}

Never assume that human physical is always healthy to be able to work all life and get always earn income. If we do not get ready early on, do not save and prepare for education for our children who come, if we fall ill it would not be possible to work so do not expect to fund our children's education. The best solution is to work hard, strive to be healthy by maintaining rest, and eating healthy foods is also the best choice to maintain health.

\section{RESULT AND DISCUSSION}

\section{A. Sources of Weakness to Confront}

The sources of weaknesses that must be faced and resolved are as follows.

First, eliminate the apathy and laziness that come from personal. Apathy and lazy attitude must have happened to all of us. However, if we realize that apathy and laziness will kill our creativity and our good efforts to excel certainly throw away. Spend time, reschedule, search for information, strive to always overcome our shortcomings or our knowledge.

Second, look for connections or try to get along with people or good environment, which both have high learning spirit, endlessly creative, and willing to give each other or exchange experience.

\section{B. Logical Consequences for the Future \\ 1) For student}

The challenge to follow the progress and development of the digital and electronic world will invite and even force the learners (read: students or students) to improve themselves and learn incessantly, even comprehensive research activities towards the era of reform and transformation to society (environment), from traditional societies to agrarian societies, from agrarian societies to modern-industrial society and information-communications, and how their implications for the improvement and development of the quality of life of human resources, will continue to accelerate in accordance with harmony and balance of nature.

This is what will dismantle the learner citizens to continue to follow or will be left behind the progress of the times

\section{2) To teacher}

Flexible, accommodative, creative, innovative, and motivative learning principles will engage students to become independent, creative, and productive to meet or face a hopeful future. Improving the capacity and ability of educators should be the main priority. These efforts include opportunities provided by educators to add and develop their scholarship through further studies, training, workshops, and so forth. The process of education should also be directed to the provision of motivation for learners (read: students and students) in achieving its goals by promoting the process and even the results though. Therefore, there should be awareness from all parties about the responsibility of education (of course involving the residents of learners, teachers, principals, policy makers/Head of Education Office, parents, community, and even the world of work as a forum for learners to live and work together to succeed together. 
Improved orientation and education system needs to be handled seriously and continuously according to the demands, guidance, and challenges of the times. Education should be directed to the process of skill formation (skills) are high for learners. Therefore, in the learning process undertaken, necessary balance of learning from the planning, process, based on theory and application (practice). Learning process should prioritize and prioritize learning based or oriented to students (student center oriented).

\section{3) To the principal}

The presence of globalization requires not only a fundamental change for every individual in view of the flow of globalization as a necessity, but more importantly it is a compulsion, and can even be said as a threat. In the process of dealing with a threat is certainly needed a resilient human resources, high fighting power, good character, and more importantly not only clever, but also brave. To make it happen then this is where education should feature a leader or leader as part of an answer about the threat of globalization. Education is challenged to be able to educate and produce highly qualified graduates instead of being otherwise barren or passive in the face of the obstacles and challenges of various advances in the dynamics of globalization.

\section{4) To the policy makers}

Policymakers work closely with principals and teachers, working hard to produce quality generation according to some of the challenges of globalization. Educational institutions should be able to prepare graduates who are ready to dive and compete with foreign workers who have entered the global market in this era. If human resources are resilient, reliable, tenacious, highly competitive, cohesive, innovative and autonomous, then policy makers will be able to directly or indirectly reduce the educated unemployment rate that occurs today will gradually decrease or decrease, a radically unanswerable answer would be no unemployment.

\section{CONCLUSION}

In accordance with a special term that describes the difficulty or hurdles of society (including learners) in the face of the complexity of life in the era of mondial is gaptek (technology stutter). Technological advances are fast-paced and innovative, and creative, demanding the community to be willing and able to follow the rate of development. Without willingness, ability, and tenacity (adversity), they (the community and learners) will certainly be left behind in following the pace of technological development. This will have an impact on the total failure of his life (can not work, difficult to communicate, difficult to transact, etc.).

For that, all the lines, whether the level of student/ learner, teacher (including lecturer), principal (including rector), policy maker (institutional control) must synergize welcome and be kind, full of awareness to strive, willing and able to recognize and follow the technological advances of this era.

\section{References}

Arief, A. (2018). Tantangan pendidikan di era globalisasi. Retrieved from http://derumotivasi.blogspot.co.id/2009/12/tantanganpendidikan-di-era-globalisasi.html

Azan, K. (2017). Tantangan pendidikan di era globalisasi. Retrieved from www.kompasiana.com/khairulazan130320/59dc880e3f8 bf43be42512e2/tantangan-pendidikan-di-eraglobalisasi.

Budianto, Imam. (2017). Apakah Iondonesia sudah siap dengan era digital. Retrieved from http://winstarlink.com/apakah-indonesia-sudah-siapdengan-era-digital

Budiyono, S. (2018). Era mondial, era digital, era masyarakat global 1. Klaten: Joglo Pos. Edisi 566.Th.XI. 1 s/d 7 Januari 2018.

Budiyono, S. (2018). Era mondial, era digital, era masyarakat global 2. Klaten: Joglo Pos. Edisi 567.Th.XI. 8 s/d 14 Januari 2018.

Dewiyana, H. (2006). Kompetensi dan kurikulum perpustakaan: paradigma baru dan dunia kerja di era globalisasi informasi. Pustaha (Jurnal Studi Perpustakaan dan Informasi), 2(1). Retrieved from http://ced.petra.ac.id/index.php/pus/article/view/17219

Ferdiana, Ridi, Randiu Eka, \& Ibnu Fausan. (n.d.). Petunjuk praktis microsoft office 365 bagi institusi pendidikan dan organisasi. Yogyakarta: Microsoft Inovation Center.

Friedman, Thomas L. (2005). The world is flat: a brief story of the twenty first century. New York: Picador I Farrar, Straus, and Giroux.

Kaku, M., Visions. (1997). How science will revolution the 21 st century. New York. Anchor Books.

Kurniawan, Khaerudin. (1999). Arah pendidikan nasional memasuki milenium ketiga. Suara Pembaharuan, Januari 1999.

Kusuma, Wijaya. (2017). Menyikapi era digital" dalam Okezone goes to campus. Retrieved from https//:ekonomi okezone.com

Pranggono, Bambang. (2001). Pendidikan tinggi di era digital dan tantangan bagi Unisba, Mimbar, XVII(1), 119.

Pratiwi, Heni. (2013). Tantangan pendidikan di era globalisasi ekonomi. Retrieved from http://izzaucon.blogspot.co.id/2014/06/tantanganpendidikan-di-era-global.html.

Rifa'i, Ilyas. (2018). Tantangan pendidikan multikultural dalam era globalisasi di Indonesia. Retrieved from http://stai-

siliwangi.ac.id/index.php?option=com content \&view=a rticle\&id=74:tantangan-pendidikan-multikulturaldalam-era-globalisasi-di-indonesia\&catid=35:islamicavol-2-no-2\&Itemid=70\&i=1

Sahlan, (2013). Empat alasan pentingnya dana pendidikan. Retrieved 
http://www.neraca.co.id/article/28887/empat-alasanpentingnya-dana-pendidikan

Siregar, Edmiraldo. (2017). Mereka yang terpuruk di era digital. Koran Sindo Reportase. 2017. Retrieved from https//:ekonomi okezone.com.

Susbandono, PM. (2017). Ketersediaan SDM di era digital masih jauh dari harap. Koran Sindo Reportase. Retrieved from https//:ekonomi okezone.com.

Uly, Yohana Artha. (2017). Era digital, kemenaker: semua industri harus segera beradaptasi. Retrieved from https//:ekonomi okezone.com. 